\title{
Long-term direct and indirect effects of the 'Exxon Valdez' oil spill on pigeon guillemots in Prince William Sound, Alaska
}

\author{
Gregory H. Golet ${ }^{1, *}$, Pamela E. Seiser ${ }^{2}$, A. David McGuire ${ }^{3}$, Daniel D. Roby ${ }^{4}$, \\ Julian B. Fischer ${ }^{1}$, Katherine J. Kuletz ${ }^{1}$, David B. Irons ${ }^{1}$, Thomas A. Dean ${ }^{5}$, \\ Stephen C. Jewett ${ }^{6}$, Scott H. Newman ${ }^{7}$ \\ ${ }^{1}$ US Fish and Wildlife Service, 1011 East Tudor Road, Anchorage, Alaska 99503, USA \\ ${ }^{2}$ Department of Biology and Wildlife, University of Alaska, Fairbanks, Alaska 99775, USA \\ ${ }^{3}$ USGS, Alaska Cooperative Fish and Wildlife Research Unit, University of Alaska, Fairbanks, Alaska 99775, USA \\ ${ }^{4}$ USGS, Oregon Cooperative Fish and Wildlife Research Unit, Oregon State University, Corvallis, Oregon 97331, USA \\ ${ }^{5}$ Coastal Resources Associates, 5674 El Camino Real, Suite M, Carlsbad, California 92008, USA \\ ${ }^{6}$ University of Alaska, School of Fisheries and Ocean Sciences, Fairbanks, Alaska 99775, USA \\ ${ }^{7}$ Wildlife Health Center, School of Veterinary Medicine, University of California, Davis, California 95616, USA
}

\begin{abstract}
We conducted a study to determine mechanisms constraining population recovery of pigeon guillemots Cepphus columba following the 1989 'Exxon Valdez' oil spill. We asked whether recovery was limited by continuing exposure to residual oil, reduced prey availability, or other causes. Our approach was to compare demographic, physiological, and behavioral parameters between an oiled site pre- and post-spill, and between the oiled site and an unoiled site post-spill. Adult mass, body condition, and nestling survival were significantly lower at the oiled site post-spill compared to pre-spill. After the spill, guillemots increased in number at the unoiled site and chicks fledged at significantly heavier weights than at the oiled site, where populations remained depressed. Elevated hepatic cytochrome P4501A (CYP1A), aspartate aminotransferase (AST), and lactate dehydrogenase (LDH) enzyme activities detected in adult guillemots a decade after the spill at the oiled site suggest that continued exposure to residual oil may have limited population recovery, although reduced availability of sand lance, a preferred forage fish, may have also played a role. Previous studies conducted at the oiled site demonstrated that guillemot chick growth and reproductive success were positively related to the percentage of high-lipid forage fishes, such as sand lance, in the chick diet. Aspects of sand lance life history and the pattern of 'Exxon Valdez' oil deposition strongly suggest that sand lance were impacted by the spill, although we lack direct evidence of this, and reductions in this species' abundance may have also resulted from natural causes. Our study suggests that the recovery of a top-level generalist predator may be constrained by both direct effects (continued exposure to residual oil) and indirect effects (reduced availability of a key prey species) following a large-scale perturbation. Furthermore, it demonstrates that recovery following oil spills may take considerably longer for certain species than the few years that have been proposed as typical for marine birds.
\end{abstract}

KEY WORDS: 'Exxon Valdez' · Oil spills · Marine birds · Cepphus columba $\cdot$ Pigeon guillemot $\cdot$ Prince William Sound $\cdot$ Blood parameters $\cdot$ Reproductive performance

Resale or republication not permitted without written consent of the publisher

\section{INTRODUCTION}

${ }^{*}$ Present address: The Nature Conservancy, Sacramento River Project, Chico, California 95928-5614, USA. E-mail: ggolet@tnc.org
It is well recognized that oil spills can have immediate adverse effects on wildlife populations because 
organisms are often killed outright and en masse following exposure (Bourne et al. 1967, Dunnet 1982). Nonetheless, quantifying population-level impacts can be very difficult. Pre-spill population estimates are often unavailable, and initial impact mortalities due to oiling are typically hard to quantify (Parrish \& Boersma 1995, Piatt \& Ford 1996). Estimating the duration of sustained injury and identifying mechanisms that constrain population recovery following initial impacts is more challenging still, as this requires that both preperturbation and current population status be known.

When pre-spill population estimates are available, they are often not comprehensive estimates. For marine birds and mammals, for example, pre-spill population estimates are typically based on counts of breeding adults at their colonies. Assessing injury based upon these counts may underestimate impacts, however, as mortalities of subadults and non-breeders may not be accounted for, and mortalities of breeders may be masked when non-breeders fill vacancies at the colony. Non-breeder replacement may explain why colony-based studies typically identified oil-spill effects on seabirds as short-lived (Birkhead \& Hudson 1977, Stowe 1982, Boersma et al. 1995), even though the projections of empirical population models suggest that effects should be longer lasting (Samuels \& Lanfear 1982). Empirical support for the notion that colony-based studies in themselves present inadequate estimations of population injury comes from east Britain, where the death of 30000 auks in late winter had no detectable effects on nearby breeding populations in the subsequent spring (Harris \& Wanless 1984).

A better approach for assessing injury to marine bird populations involves comparing geographically broad-based population surveys made before and after a perturbation. Surveys of this type were conducted for marine birds in Prince William Sound (PWS) before and after the 1989 'Exxon Valdez' oil spill (hereafter EVOS). Using a before-after-controlimpact design with paired sampling (Osenberg et al. 1994), Murphy et al. (1997) compared pre- and postspill (through 1991) densities of birds along oiled and unoiled shorelines in PWS. Their analysis revealed that of all marine birds in PWS, the impacts of the spill on abundance and distribution were most pronounced for pigeon guillemots Cepphus columba. Murphy et al. (1997) stated, 'The Pigeon Guillemot was the one species that...showed persistent declines in overall abundance relative to pre-spill baseline, (and further was the marine bird species that) showed the greatest negative impacts and the fewest signs of recovery'. Irons et al. (2000) performed analyses similar to those of Murphy et al. (1997), but based on surveys that covered a wider geographic area, over a longer time span. The results corroborated those of Murphy et al.
(1997) but further demonstrated that spill effects continued through 1998, 9 yr after the oiling event.

Given clear evidence that guillemot populations in oiled areas of PWS were negatively impacted and not recovering, we initiated a study to determine whether recovery was limited by continuing exposure to residual oil, prey availability, or other causes. Our approach was to compare demographic, behavioral, physiological, and dietary parameters between an oiled site preand post-spill, and between the oiled site and an unoiled site post-spill. Our study subsumes data previously collected and analyzed by Oakley \& Kuletz (1996). Oakley \& Kuletz assessed the effects of EVOS on pigeon guillemots by comparing components of reproductive success measured at an oiled site in the 2 yr immediately following the spill with measures drawn from the same site a decade prior. They found that overall productivity was significantly lower after the spill, but did not attribute the difference to an oil spill effect. Instead, increased post-spill predation on guillemot nests was suggested as the cause (Oakley \& Kuletz 1996). Their study did, however, show that chick growth rates tended to be lower following the spill, leaving open the possibility that residual oil continued to affect the birds.

In this paper we suggest that the recovery of a toplevel generalist predator may be constrained by both direct effects (continued exposure to residual oil) and indirect effects (reduced availability of a key prey species) following a large-scale perturbation, and further, that recovery following oil spills may take considerably longer for certain species than the few years that have been proposed as typical for marine birds.

Our study fits into a larger context of work that reports on effects of EVOS on a wide assemblage of marine organisms (reviewed by Peterson 2001) including invertebrates (Fukuyama et al. 2000), fishes (Jewett et al. 2002), mammals (Bowyer et al. 1995, BenDavid et al. 2001, Bodkin et al. 2002, Dean et al. 2002) and birds (Irons et al. 2000, Esler et al. 2002).

\section{BACKGROUND}

Following the grounding of the supertanker 'Exxon Valdez' on Bligh Reef on the morning of 24 March $1989, \sim 4.1 \times 10^{7} 1$ of North Slope crude oil spilled into the waters of PWS. Although approximately $20 \%$ of the spilled oil volatilized, and a further $20 \%$ left the Sound, $60 \%$ of the spilled oil was retained in PWS, either sinking or coating shorelines (Wolfe et al. 1994). Oil spread from the spill site southwest across PWS, first hitting the central island groups (Naked \& Knight Islands), and then mainland shorelines and adjacent islands (Galt et al. 1991, Neff et al. 1995) (see inset map 
of Fig.1). The 'Exxon Valdez' spill differed from other large spills (e.g. the TV 'Braer' spill) because it occurred in an area protected from large seas by barrier islands, and because the bulk of the spilled oil formed a slick that did not disperse into the water column (Kingston 1995). Although oil concentrations declined rapidly in the first few years following the spill (Neff et al. 1995, O'Clair et al. 1996), as recently as 1997, residual oil from EVOS was still found in many intertidal and subtidal zones of the Sound (Hayes \& Michel 1999).

An estimated 250000 seabirds were killed outright by EVOS (Piatt \& Ford 1996). Of approximately 30000 oiled carcasses that were recovered following the spill, $\sim 12 \%$ were collected in PWS, with alcids $(32 \%$, primarily murres Uria aalge), sea ducks (26\%), and cormorants $(16 \%)$ dominating the carcass recoveries (Piatt et al. 1990). Various aspects of their life history may make alcids, and guillemots in particular, especially vulnerable to oil spills (King \& Sanger 1979). Guillemots typically forage in nearshore benthic environments, which can be significant repositories for spilled oil. They spend large portions of their time resting on surface waters and roosting on intertidal rocks, and because they have restricted foraging ranges (Ewins 1993), they may be less able to avoid oiled habitat than seabirds that forage more widely.

\section{MATERIALS AND METHODS}

Study sites. Our oiled study site was the Naked Island group, which includes Naked, Peak and Storey Islands, located in central PWS (Fig. 1). We studied guillemots Cepphus columba there for $5 \mathrm{yr}$ prior to the spill (1978 to 1981, and 1984), and 8 yr post-spill (1989 to 1990, and 1994 to 1999). Naked Island is located approximately $30 \mathrm{~km}$ from Bligh Reef, and was the first land mass hit by oil spilled by the 'Exxon Valdez'. The near-shore habitat of the Naked Island group includes many bays and passages with a shallow $(<30 \mathrm{~m})$ shelf habitat radiating about $1 \mathrm{~km}$ from shore. The islands are forested to their summits $(<400 \mathrm{~m})$, mostly with sitka spruce Picea sitchensis and western hemlock Tsuga heterophylla. Guillemots nest semi-colonially along the island's rocky shore- lines in cavities beneath tree roots overhanging crumbling cliffs, in rock crevices, and among boulders on talus slopes. Other members of the Alcidae breeding on these islands include marbled murrelets Brachyramphus marmoratus, parakeet auklets $C y$ clorrhynchus psittacula, tufted puffins Fratercula cirrhata, and horned puffins F. corniculata. Populations of all these species have declined appreciably in PWS since the 1970 s, presumably due to large-scale changes in forage fish abundance in the region (Agler et al. 1999).

Our unoiled study site was located in PWS (Fig. 2). Most of our work was conducted on Jackpot Island, a small low-elevation island with a shoreline of low $(<25 \mathrm{~m})$ cliffs and 1 small bay. We studied guillemots there from 1993 to 1998. A sound-wide survey conducted in 1993 showed that Jackpot Island had the highest density of guillemots in all of PWS (Sanger \& Cody 1994). Horned puffins also nest on the island. In 1998 and 1999, guillemots breeding at Icy Bay were captured for liver biopsies and blood collection. Icy Bay is situated $7.4 \mathrm{~km}$ south of Jackpot Island, and was also unoiled. 


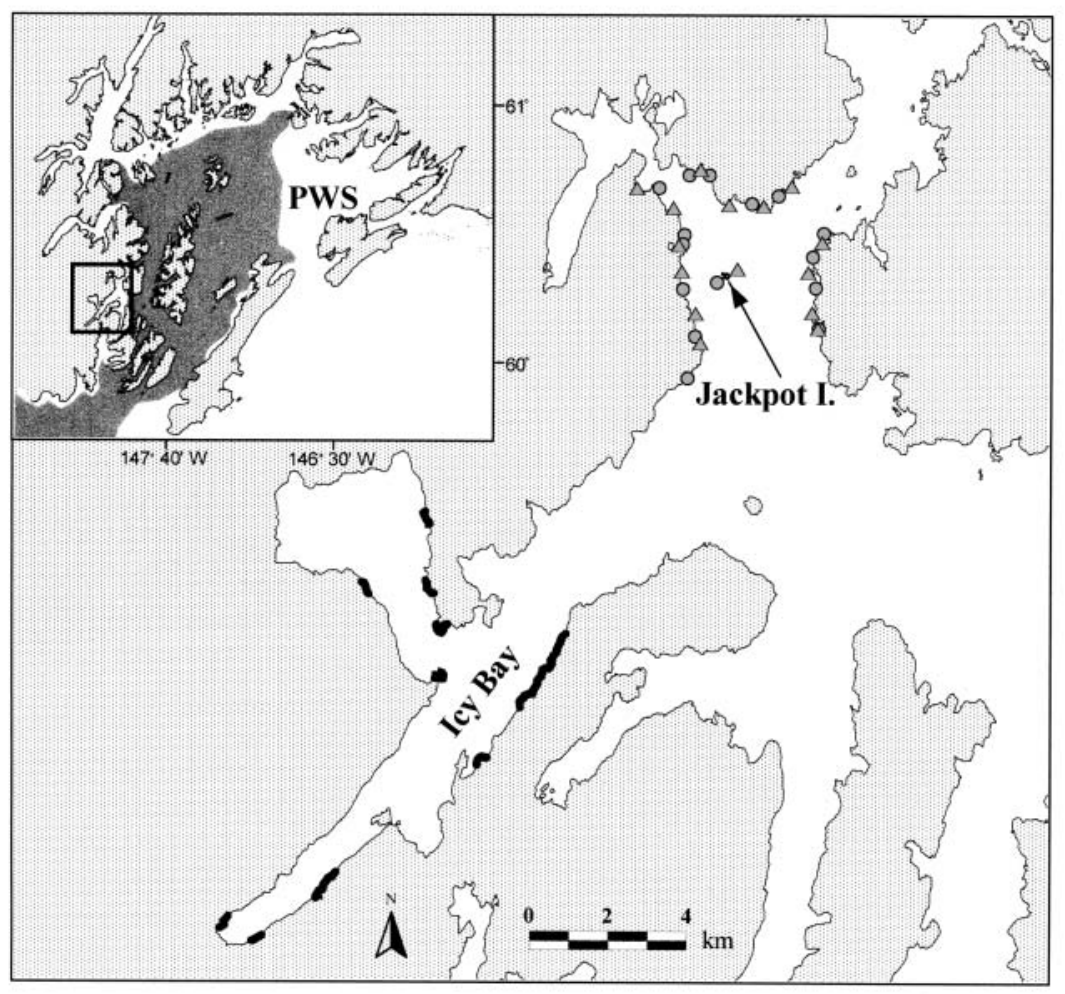

Fig. 2. Map of the unoiled study site. Study areas of pigeon guillemot Cepphus columba colonies are depicted by thickened shoreline. Dive transect locations are shown as circles (1996 sites) or triangles (1997 sites). Inset map shows locations of the unoiled colonies (inside box) and the oiled area (dark shading) within Prince William Sound, Alaska

and 22 unoiled clusters. (See Irons et al. [2000] for further details on this survey methodology.)

We conducted whole-island censuses of guillemots along the shores of Naked, Peak, Storey, Smith, Little Smith, and Jackpot Islands in late May and early June. The specific dates of the surveys varied by year, and were set to coincide with earlymorning high tides, when guillemot attendance peaks (Vermeer et al. 1993). Years in which counts were made are indicated on Fig. 4. Censuses were conducted in a manner identical to that described above for Sound-wide surveys.

Continuing exposure to oil. To determine if guillemots faced continued exposure to residual 'Exxon Valdez' oil, we assayed hepatic cytochrome P4501A (CYP1A), a liver enzyme that is rapidly induced in many vertebrate species following exposure to polycyclic aromatic hydrocarbons (PAHs) (Collier \& Varanasi 1991). PAHs are a refractory class of petroleum hydrocarbons that have a high potential for exerting toxicity in birds (Leighton 1993). Elevated levels of CYP1A are transient following exposure to rapidly metab-

\section{Population assessment}

Guillemot populations were assessed before and after EVOS by (1) conducting shoreline surveys as part of a US Fish and Wildlife Service monitoring program designed to estimate the densities of marine birds over the entire PWS, and (2) conducting whole-island censuses to estimate populations of guillemots at locations where this species was known to concentrate during breeding.

Sound-wide surveys were conducted during June and July over 8 yr (see Fig. 3). Transects were selected by stratified-random sampling to account for differences in marine habitat. Surveys were conducted from $8 \mathrm{~m}$ boats piloted $100 \mathrm{~m}$ offshore. One observer scanned continuously with binoculars from each side of the boat, counting all guillemots observed within a sampling window that extended $100 \mathrm{~m}$ to either side of, in front of, and above the survey vessel. Intertidal rocks, beaches, and uplands were also scanned for guillemots. In total, 123 transects were sampled. Transects varied in length, but were typically several $\mathrm{km}$ long. For analysis, transects were grouped into 23 oiled olized compounds such as PAHs, and thus are indicative of recent exposure to contaminants (J. Stegeman pers. comm.).

CYP1A was assayed following liver biopsies of 26 chicks (14 from the oiled colonies [on Naked and Storey Islands] and 12 from unoiled colonies [on Jackpot Island and in Icy Bay]) that were 18 to $24 \mathrm{~d}$ old, and 24 adult guillemots (13 from oiled colonies [on Naked and Storey Islands] and 11 from unoiled colonies [in Icy Bay]). The surgeries were performed by an avian veterinarian in a field laboratory during 20 to 26 July 1998 (chicks) and 15 to 23 June 1999 (adults). Details of the anesthesia and surgery procedures are provided in Degernes et al. (2002).

Blood biomarkers. To determine whether guillemots were adversely affected by continued exposure to residual oil, we assessed blood parameters of adult birds at the oiled and unoiled sites. Blood samples were collected from adult guillemots at the oiled site (Naked and Storey Islands) during 14 June to 12 July 1998, and during 15 to 18 June 1999. At the unoiled site, samples were collected from Jackpot Island during 10 July to 5 August 1998, and at Icy Bay during 21 
to 23 June 1999. This investigation complemented the work of Seiser et al. (2000), who studied blood parameters in 1997 and found no obvious oil-induced effects on chicks, but recommended that adults be examined further. Seiser et al.'s recommendation was based largely on the finding that aspartate aminotransferase (AST) was significantly elevated in breeding guillemots at the oiled site relative to the unoiled site. Elevations of AST, as well as elevations of lactate dehydrogenase (LDH), are symptomatic of liver damage, which commonly results from oil exposure (Campbell 1986). These blood parameters may also become elevated following damage to other tissues, however, including kidney, lung, myocardium, or skeletal muscle (Franson 1981). A recent study of mink Mustela vison demonstrated that chronic low-level ingestion of food contaminated with Alaska North Slope crude oil resulted in long-term increased LDH activity (Mazet et al. 2000), further suggesting the usefulness of this enzyme for assessing oil exposure. In addition to assaying activity levels of AST and LDH, we assayed creatine kinase and alkaline phosphatase. Serum was analyzed for concentrations of bile and uric acids, corticosterone (1998 samples only), sodium $(\mathrm{Na})$, potassium $(\mathrm{K})$, chloride $(\mathrm{Cl})$, calcium $(\mathrm{Ca})$, phosphorus $(\mathrm{P})$, total $\mathrm{CO}_{2}$, glucose, total protein, albumin, blood urea nitrogen, and cholesterol. Anion gap, albumin:globulin ratio (A:G ratio), and globulin concentration were calculated. Previous studies of guillemots (Peakall et al. 1980) and other seabirds (Fry \& Lowenstine 1985, Leighton 1985, 1993, Khan \& Ryan 1991, Peakall and Shugart 1993, Rattner et al. 1996, Newman et al. 2000) suggested that oil exposure might affect these blood parameters.

Approximately $2.0 \mathrm{ml}$ of blood was aseptically obtained from the metatarsal vein using a 23 gauge hypodermic or butterfly needle and $3 \mathrm{ml}$ syringe. Blood was immediately transferred into Microtainer ${ }^{\mathrm{TM}}$ serum separator tubes (Becton-Dickinson) and stored in coolers for $<3 \mathrm{~h}$ prior to centrifugation. Samples were centrifuged in a Triac Centrifuge ${ }^{\mathrm{TM}}$ (Clay Adams) for $15 \mathrm{~min}$ at $3500 \mathrm{rpm}$. Sera was transferred with disposable polyethylene pipettes into $1.5 \mathrm{ml}$ plastic microcryovials (Out Patient Services), which were subsequently stored frozen until analyses at the Veterinary Medical Teaching Hospital (University of California Davis).

Adult body condition. We compared adult body condition at the oiled and unoiled sites because previous studies have shown that oiling adversely affects this parameter in seabirds (Culik et al. 1991, Fowler et al. 1995). Adult guillemot body condition was determined by scaling body mass by body size. Two techniques were used. For the pre- versus post-spill comparison, we calculated body condition with a simple ratio index (body mass:wingcord $^{3}$ ) (Moeller 1987). We used this analysis method because few morphometric measurements were taken on individual birds in pre-spill years. Additional morphometric parameters were assessed in post-spill years, enabling us to compare body condition between sites with a more sophisticated method, a principle components residual index (Reid 1987, Golet \& Irons 1999). Calculating post-spill body condition involved: (1) establishing an index of body size from measurements of captured adults, (2) developing regression equations between the index of body size and body mass for the study population at large, and (3) applying measurements of our study animals to these equations and using residuals to generate individual body-condition estimates. This method of estimating body condition is recommended over other techniques because the metric is independent of an individual's linear size (Piersma 1984, Piersma \& Davidson 1991, Jakob et al. 1996).

To establish the body size index, we performed a principle components analysis (PCA) (SYSTAT 1997) on measurements of 24 adults (13 from Naked Island and 11 from Icy Bay) captured during 15 to 23 June 1999. We weighed and individually color-marked each bird, and measured the tarsus, head-plus-bill, and wingcord lengths. With PCA, we generated weighting coefficients that described positive covariance among the linear measurements. These coefficients had variable loadings (tarsus 0.57, head-plus-bill 0.29, and wingcord 0.53), and the first principle component accounted for $48 \%$ of the variance in the original measures. Standardized measurements were multiplied by these coefficients and added together to produce a PCA factor score (our bodysize index). By regressing body mass (grams) on the body-size index, we developed a least-squares regression $\left(y=478.3+11.5 x, n=24, r^{2}=0.19, p=0.034\right)$ that allowed us to predict the mass of a bird given its size. Although this equation has relatively low predictive power, it serves as a useful benchmark for comparing mean levels of condition in groups of individuals.

We calculated the body condition of experimental birds by subtracting the predicted weight of each bird (based on the regression equation) from its actual weight, dividing this difference by the predicted weight, and then multiplying the resulting quotient by 100. This value (our body-condition index) represents the percent by which a bird's measured weight differs from what it was expected to weigh, given its size, thus providing a rough estimate of each bird's level of nutrient reserves.

Prey availability. To determine if the recovery of oilimpacted populations was constrained by prey availability, we performed dive transects at guillemot foraging areas near the study colonies. Demersal fish population densities were estimated in 1996 and 1997. A total of 60 sites were surveyed (15 sites area ${ }^{-1} \mathrm{yr}^{-1}$ ). 
Sites were systematically selected within a $4 \mathrm{~km}$ radius of major guillemot nesting areas (Figs. 1 \& 2). At each site, we counted demersal fishes along 2 transects running perpendicular to shore. Transects extended $30 \mathrm{~m}$ from shore, or in cases where the shoreline was steep, until a depth of $15 \mathrm{~m}$ was attained. The 2 transects originated $10 \mathrm{~m}$ to either side of the shoreline midpoint at each site. Demersal fishes were counted along a $1 \mathrm{~m}$ wide swath on each transect while moving aside algae and other vegetation. All fish $<15 \mathrm{~cm}$ were identified to the family level, and classified as 1 of 2 size classes ( 1 to $8 \mathrm{~cm}$ and 8 to $15 \mathrm{~cm}$ ). For comparison purposes, we calculated the average density of fishes (number observed per $100 \mathrm{~m}^{2}$ ) at each site.

Chick diet. We studied chick diet to determine if recovery of oil-impacted populations was constrained by food availability. Chick diet composition and delivery rates were determined by observing prey items held crosswise in the bills of adult guillemots as they provisioned their young in the nest. Feeding observations were made with binoculars and spotting scopes from land-based blinds at the oiled site (Naked Island) before and after the spill, and at the unoiled site (Jackpot Island) after the spill. Years in which chick diet and delivery rates were determined are indicated in Appendixes $1 \& 2$. We watched from each blind for an average of 4 full days, alternating our observation points to ensure that the diet of chicks aged 8 to $30 \mathrm{~d}$ was well documented. Because guillemots often pause on the water or on rocks in front of their nests before making deliveries to their chicks, we were usually able to identify the prey items they carried in their bills. During our blind watches, prey items were identified to the lowest possible taxon, but for the purposes of this paper, observed prey items were divided into 1 of 2 categories based on lipid content. High-lipid fishes included Pacific sand lance Ammodytes hexapterus, Pacific herring Clupea pallasii and smelt (Osmeridae), whereas low-lipid fishes included gadids Gadidae spp., sculpins Cottidae spp., blennies Stichaeidae and Pholidae spp., and other demersal fishes. We report the percent high-lipid fishes in the chick diet because this parameter is positively related to guillemot chick growth and reproductive success (Golet et al. 2000). High-lipid fishes probably confer reproductive advantages to guillemot chicks because they have high energy densities ( $\mathrm{kJ} \mathrm{g}^{-1}$ fresh mass) (Barrett et al. 1987, Hislop et al. 1991, Van Pelt et al. 1997, Anthony et al. 2000), high metabolizable energy coefficients (Massias \& Becker 1990, Brekke \& Gabrielsen 1994), and are not lacking in other nutrients because lipids tend to replace water and not protein (Harris \& Hislop 1978, Anthony et al. 2000).

Chick growth and reproductive success. Previous studies have demonstrated that oil exposure can lead to reductions in egg laying (Ainley et al. 1981), chick growth rates (Miller et al. 1978, Butler \& Lukasiewicz 1979, Andres 1999), hatching success, and nestling survival (Trivelpiece et al. 1984, Fry et al. 1986). To test for such effects, we measured chick growth and reproductive success at the oiled site (Naked and Storey Islands) pre- and post-spill, and at the unoiled site (Jackpot Island) post-spill. Years in which chick growth and reproductive success were determined are indicated in Appendixes 1 \& 2. We visited all known nests at least once every $5 \mathrm{~d}$ from the egglaying stage until the chick(s) fledged. At hatching we marked the web of the foot of alpha (the first to hatch, or larger chick, of 2-chick broods), and beta (the second to hatch, or smaller chick, of 2-chick broods) chicks to distinguish them from one another until they were old enough for banding. Chicks were weighed and measured to determine growth rates, calculated as the slope of the regression of mass on age for chicks between 8 and $18 \mathrm{~d}$ post-hatch, the linear phase of the growth cycle (Emms \& Verbeek 1991, Ewins 1993). Because this growth measure is not influenced by the particular asymptote that individual chicks attain (Hussel 1972, Gaston 1985), it is independent of peak and fledging mass, which we also report. We define peak mass as the highest mass measured, and fledging mass as the last mass measured prior to fledging. Peak and fledging mass have been shown to affect fledging success and subsequent survival (Perrins et al. 1973).

Based on observations made during nest visits we determined reproductive success parameters, including clutch size, hatching success (eggs hatched per egg laid), nestling survival (chicks fledged per egg hatched), overall productivity (chicks fledged per egg laid), and brood size at fledging. We calculated predation rate as the percent of total nests observed that showed evidence of predation (e.g. egg shell fragments, blood stains, dead chicks).

Statistics. For most post-spill comparisons, we used general linear models (GLMs) to test for 'site' (oiled vs unoiled) effects. We included 'year' and 'chick type' (separate categories designated for alpha, beta, and single chicks) as categorical random factors in our GLMs when appropriate. For binomially-distributed data we compared multiple logistic regression models, and tested for significance by assessing the deviance (expressed as a likelihood ratio statistic) of saturated models and models lacking particular effects (Agresti 1990). For pre- versus post-spill comparisons, we used individual year means as our sample units. We used the Lilliefors test to assess normality with variables having continuous frequency distributions. In some instances we performed transformations to satisfy assumptions of parametric tests; otherwise we used 
non-parametric tests (Kruskal-Wallis or Mann-Whitney $U$ ). For all $t$-tests we assumed unequal variance. Data on fish abundance were log-transformed (log $[$ density +0.1$]$ ) prior to analyses. For contingency-table analyses, log-likelihood ratio tests (G-tests) were used (Fienberg 1970, Bishop et al. 1975). For $G$-tests involving only 2 classes, the Williams correction was applied to reduce the likelihood of Type I errors (Sokal \& Rohlf 1995). All tests are 2-tailed, and statistical significance was assigned at $\mathrm{p}<0.05$. We report mean values $\pm 1 \mathrm{SE}$

\section{RESULTS}

Table 1 summarizes the results of pre- versus post-spill comparisons at the oiled site and post-spill comparisons between the oiled and unoiled sites.

\section{Guillemot populations}

Cepphus columba populations were negatively affected by EVOS and, as of 1998, had not recovered to pre-spill levels (see Fig. 3 and Irons et al. 2000). In the first few yr following the spill (1989 to 1993), guillemot

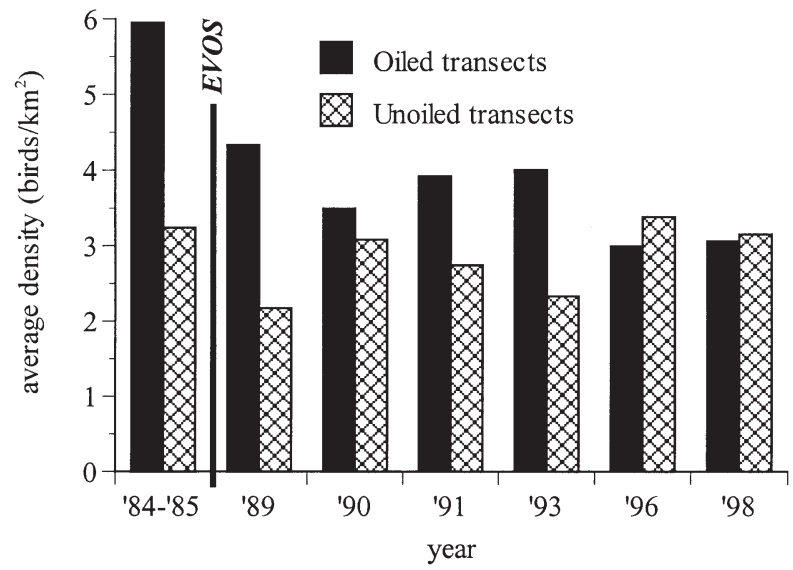

Fig 3. Cepphus columba. Densities along oiled and unoiled shorelines before and after the 'Exxon Valdez' oil spill. Densities were determined by surveys conducted during June and July. Survey transects $(n=123)$ were selected by stratifiedrandom sampling to account for differences in marine habitat. Surveys were conducted from $8 \mathrm{~m}$ boats piloted $100 \mathrm{~m}$ offshore. All guillemots observed within a sampling window that extended $100 \mathrm{~m}$ to either side of, in front of, and above the survey vessel were counted. Intertidal rocks, beaches, and nearshore uplands were also scanned for guillemots

densities appeared depressed relative to pre-spill levels along both the oiled and unoiled transects; however, the magnitude of the decline was greater along oiled transects. In more recent years (1996 and 1998), guillemot densities along oiled shorelines continued to decline, and for the first time fell below what was observed along unoiled coastlines, further suggesting that recovery had not taken place.

Whole-island censuses indicate that guillemots at the oiled and unoiled study sites exhibited divergent population trends following EVOS (Fig. 4). The population at the unoiled site increased significantly during 1993 to 1998, while no significant post-spill trend was observed at the oiled site. The population multiplication rate $(\lambda)$ was 1.05 at the unoiled site (Fig. 4B), and 0.98 at the oiled site (Fig. 4A).

\section{Continuing exposure to oil}

Ten years after the spill, adults from the oiled site had significantly higher CYP1A activity in the liver than adults from the unoiled site (oiled: $3.1 \pm$ 0.4 pmol $\mathrm{min}^{-1} \mathrm{mg}^{-1}, \mathrm{n}=12$ birds; 

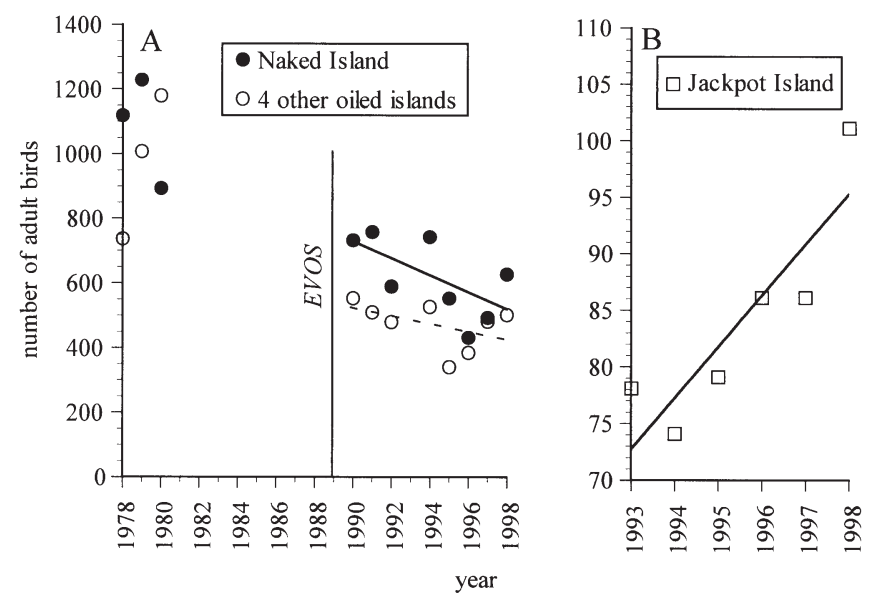

Fig. 4. Cepphus columba. Population trends at oiled (A) and unoiled (B) study colonies in Prince William Sound, Alaska, before and after the 'Exxon Valdez' oil spill. Post-spill trends at oiled colonies are similar when considering Naked Island $\left(y=-27.1 x+54589, \mathrm{n}=8 \mathrm{yr} \mathrm{r}^{2}=0.42, \mathrm{p}=0.084\right.$ : solid regression line), or 4 other oiled islands (Storey, Peak, Smith, and Little Smith) for which comparable census data were collected $\left(y=-10.4 x+22252, n=8 y r, r^{2}=0.17, p=0.31\right.$ : dashed regression line). The population of guillemots at Jackpot Island, the unoiled colony, increased significantly post-spill $\left(y=4.5 x-8924, \mathrm{n}=6 \mathrm{yr}, \mathrm{r}^{2}=0.78, \mathrm{p}=0.020\right)$

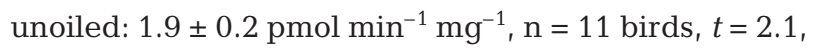
$\mathrm{p}=0.020$; Fig. 5B). Nestlings measured $1 \mathrm{yr}$ earlier, however, did not show a statistically significant difference in this parameter between the 2 sites (oiled: $4.1 \pm$ 0.4 pmol min $\mathrm{mg}^{-1}, \mathrm{n}=12$ birds; unoiled $4.7 \pm$ $0.5 \mathrm{pmol} \mathrm{min} \mathrm{mg}^{-1} \mathrm{mg}^{-1} \mathrm{n}=14$ birds, $t=2.06, \mathrm{p}=0.38$; Fig. 5A). These results suggest that adults, but not chicks, were exposed to residual petroleum hydrocarbons at the oiled site a decade after the spill. Although CYP1A activity was elevated at the oiled site, absolute CYP1A activities were low, suggesting that oil exposure was low-level. CYP1A activities were variable among individuals at the oiled site, indicating different levels of oil exposure. This finding matches expectations, given that guillemots have strong foraging-site fidelity (Golet unpubl. data) and 'Exxon Valdez' oil was patchily distributed at the oiled site (Neff et al. 1995, O'Clair et al. 1996, Wolfe et al. 1996).

Elevated CYP1A activity at the oiled site could have been caused by exposure to contaminants that did not originate with EVOS; however, we know of no other contaminant sources in PWS that are likely to explain this result. That EVOS hydrocarbons were the cause of observed differences in CYP1A activities (and blood biomarkers) is further suggested by a recent report that found no differences in marine vessel traffic between our oiled and unoiled sites (Murphy et al. 1999).

\section{Blood biomarkers}

Significant differences were detected in blood parameters of adult guillemots from the 2 sites post-spill (see Table 2). In 1998, adult guillemots at the oiled site had lower concentrations of $\mathrm{Na}, \mathrm{Ca}$, and $\mathrm{P}$, higher concentrations of $\mathrm{K}$, total $\mathrm{CO}_{2}$, glucose, and corticosterone, and higher activities of LDH than guillemots sampled at the unoiled site. In 1999, adult guillemots at the oiled site again had higher glucose concentrations and LDH activity than birds at the unoiled site. An additional difference apparent in 1999 was elevated AST activity among birds at the oiled site.

The most noteworthy differences between sites from the perspective of assessment of injury from the oil spill were the elevated AST and LDH enzyme activities found at the oiled site. Among adults sampled in 1999, significant correlations were found between both AST and LDH activities (Pearson correlation coefficient = 0.79, Bonferroni probability $<0.001$ ), and CYP1A and AST activities (Pearson correlation coefficient $=0.43$, Bonferroni probability $=0.047$ ). Simultaneous eleva-

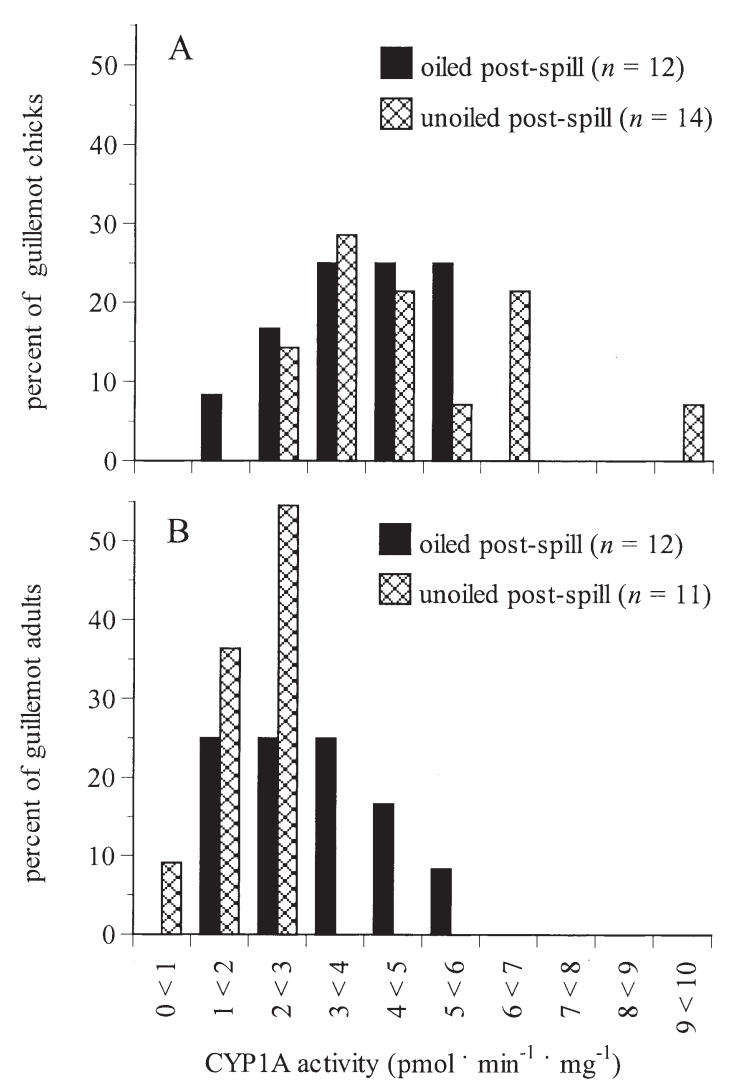

Fig. 5. Cepphus columba. Frequency histogram of CYP1A for chicks in 1998 (A), and adults in 1999 (B), at oiled (Naked and Storey Islands) and unoiled (Jackpot Island and Icy Bay) colonies in Prince William Sound, Alaska, after the 'Exxon Valdez' oil spill 
Table 2. Cepphus columba. Comparisons of adult pigeon guillemot blood parameters from oiled and unoiled sites 9 and 10 yr after the 'Exxon Valdez' oil spill in Prince William Sound, Alaska. Only those parameters for which there were differences at the $p<0.1$ level are listed; for a complete list of parameters compared between sites see 'Materials and methods'. Values presented are means $\pm \mathrm{SE}$

\begin{tabular}{|c|c|c|c|c|c|c|}
\hline Parameter & $\begin{array}{l}\text { Oiled } \\
(n=9)\end{array}$ & $\begin{array}{c}1998 \\
\text { Unoiled } \\
(\mathrm{n}=9)\end{array}$ & p-value & $\begin{array}{c}\text { Oiled } \\
(\mathrm{n}=13)\end{array}$ & $\begin{array}{c}1999 \\
\text { Unoiled } \\
(\mathrm{n}=11)\end{array}$ & p-value \\
\hline Aspartate aminotransferase (IU l $\left.{ }^{-1}\right)$ & $359 \pm 44$ & $279 \pm 28$ & 0.35 & $526 \pm 42$ & $413 \pm 42$ & 0.05 \\
\hline Bile acid $\left(\right.$ umol l l$\left.^{-1}\right)$ & $12 \pm 1$ & $18 \pm 2$ & 0.07 & $14 \pm 1$ & $14.4 \pm 1^{\mathrm{b}}$ & 0.45 \\
\hline Calcium $\left(\mathrm{mg} \mathrm{dl}^{-1}\right)$ & $7.1 \pm 0.5$ & $8.6 \pm 0.2$ & 0.02 & $9.0 \pm 0.5$ & $8.8 \pm 0.2$ & 0.62 \\
\hline Chloride $\left(\mathrm{mmol} \mathrm{l}^{-1}\right)$ & $114 \pm 1$ & $115 \pm 2$ & 0.37 & $118 \pm 1$ & $115 \pm 1^{b}$ & 0.06 \\
\hline Corticosterone $\left(\mathrm{ng} \mathrm{ml}^{-1}\right)$ & $67 \pm 9^{a}$ & $24 \pm 5$ & 0.003 & No data & No data & No data \\
\hline Glucose $\left(\mathrm{mg} \mathrm{dl}^{-1}\right)$ & $433 \pm 22$ & $333 \pm 23$ & 0.004 & $469 \pm 14$ & $436 \pm 30$ & 0.04 \\
\hline Lactate dehydrogenase $\left(\mathrm{ul} \mathrm{l}^{-1}\right)$ & $1029 \pm 168$ & $470 \pm 43$ & 0.01 & $931 \pm 82$ & $627 \pm 48$ & 0.006 \\
\hline Phosphorus (mg dl-1) & $1.0 \pm 0.2$ & $2.6 \pm 0.5$ & 0.03 & $5.4 \pm 0.8$ & $6.8 \pm 0.5$ & 0.20 \\
\hline Potassium $\left(\mathrm{mmol} \mathrm{l}^{-1}\right)$ & $2.9 \pm 0.2$ & $2.3 \pm 0.5$ & 0.03 & $4.1 \pm 0.2$ & $4.2 \pm 0.3^{\mathrm{b}}$ & 0.71 \\
\hline Sodium $\left(\mathrm{mmol} \mathrm{l}^{-1}\right)$ & $155 \pm 1$ & $157 \pm 0.3$ & 0.02 & $158 \pm 1$ & $157 \pm 1^{\mathrm{b}}$ & 0.21 \\
\hline Total $\mathrm{CO}_{2}\left(\mathrm{mmol} \mathrm{l}^{-1}\right)$ & $23 \pm 1$ & $19 \pm 1$ & 0.01 & $39 \pm 1$ & $41 \pm 1$ & 0.55 \\
\hline Uric Acid $\left(\mathrm{mg} \mathrm{dl}^{-1}\right)$ & $8.9 \pm 1$ & $14 \pm 2$ & 0.06 & $3.4 \pm 1$ & $3.5 \pm 0.5$ & 0.10 \\
\hline${ }^{\mathrm{a}} \mathrm{n}=6 \operatorname{birds}^{\mathrm{b}}{ }^{\mathrm{b}} \mathrm{n}=10$ birds & & & & & & \\
\hline
\end{tabular}

tions of these parameters are strongly indicative of a toxicological response, and support the notion that adult guillemots at the oiled site were exposed to residual oil 9 and 10 yr post-spill. Some caution must be exercised in interpreting these results, however, as AST was significantly elevated in only 1 of the 2 years.

\section{Adult body condition}

Among adult guillemots studied at the oiled site, both body mass (pre-spill: $502 \pm 3 \mathrm{~g}, \mathrm{n}=3 \mathrm{yr}$; post-spill: $478 \pm 2 \mathrm{~g}, \mathrm{n}=4 \mathrm{yr} ; t=6.1, \mathrm{p}=0.002$ ) and body condition (pre-spill: $9.2 \pm 0.1 \mathrm{~g} \mathrm{~mm}^{-3}, \mathrm{n}=3 \mathrm{yr}^{\text {i }}$ post-spill: $\left.7.9 \pm 0.1 \mathrm{~g} \mathrm{~mm}^{-3} ; \mathrm{n}=4 \mathrm{yr}_{1} t=7.7, \mathrm{p}=0.002\right)$ were significantly higher pre-spill than post-spill. Following the spill, however, there were no statistically significant differences in either of these parameters between oiled and unoiled sites (body mass: $F_{1,44}=0.32, \mathrm{p}=$ 0.58 ; body condition: $F_{1,44}=1.2, \mathrm{p}=0.28$ )

\section{Prey availability and chick diet}

Demersal prey fish availability, as determined by dive transects near guillemot colonies post-spill, was significantly greater overall at the oiled site than at the unoiled site $(\mathrm{n}=60$ transects, $t=2.87, \mathrm{p}=0.006$; Fig. 6 ). When broken down by size class, the difference was statistically significant for fishes of 1 to $8 \mathrm{~cm}$ ( $\mathrm{n}=60$ transects, $t=3.12, \mathrm{p}=0.003$ ), but not for fishes of 8 to $15 \mathrm{~cm} \mathrm{(n}=60, t=1.82, \mathrm{p}=0.075)$, although the oiled site tended to have higher densities of fishes of the larger size class as well. ANOVA analyses of log-transformed fish densities revealed no significant year $\left(F_{1,56}=0.02, \mathrm{p}=0.90\right)$ or year $\times$ site interaction $\left(F_{1,56}=1.09, \mathrm{p}=0.30\right)$ effects. These results suggest that availability of demersal prey fishes was not lower at the oiled site relative to the unoiled site 7 to $8 \mathrm{yr}$ after EVOS.

The percent high-lipid schooling fishes (sand lance, herring, smelt) in chick diets was reduced at the oiled site following EVOS. Significantly fewer high-lipid

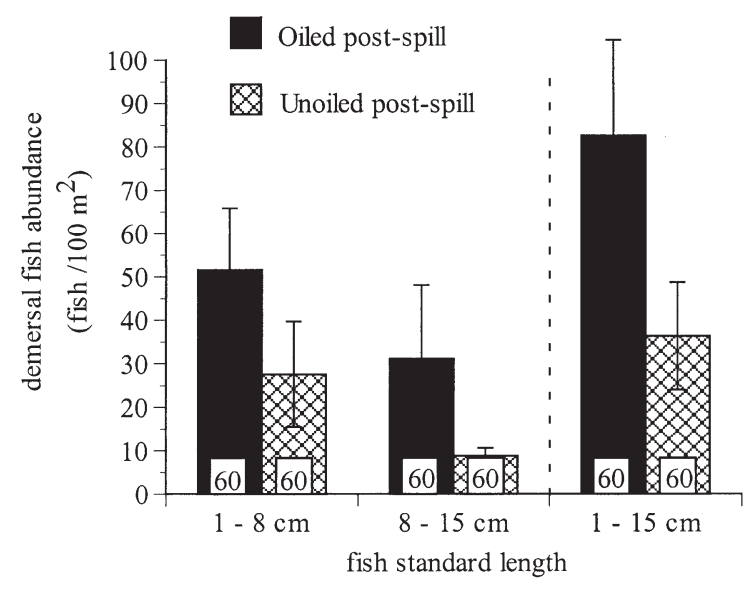

Fig. 6. Cepphus columba. Demersal fish abundance in foraging areas near oiled (Naked, Peak and Storey Islands) and unoiled colonies in Prince William Sound, Alaska, 1996 and 1997. Data from the 2 years were pooled because the difference in fish densities between years was not statistically significant (see 'Results'). Mean values $( \pm 1 \mathrm{SE}$ ) are presented, and sample sizes are indicated at the bases of the bars 

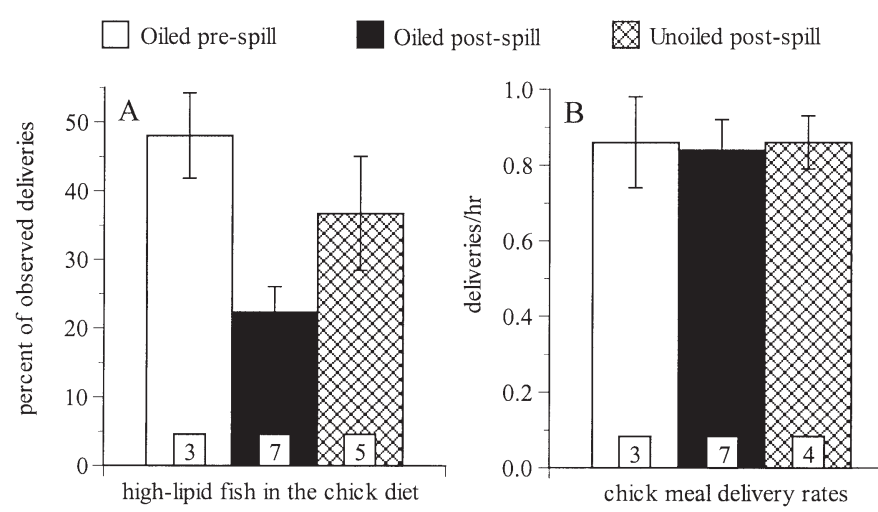

Fig. 7. Cepphus columba. Percent high-lipid fishes in chick diet (A), and chick meal-delivery rates (B), at oiled (Naked Island) and unoiled (Jackpot Island) colonies in Prince William Sound, Alaska, before and after the 'Exxon Valdez' oil spill. Values are grand means $( \pm 1 \mathrm{SE})$ of individual year means. Sample sizes are indicated at the bases of the bars
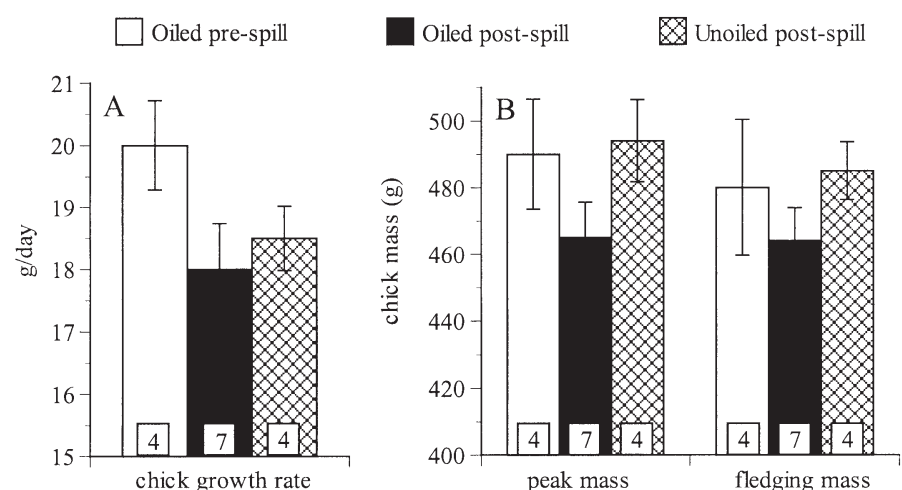

Fig. 8. Cepphus columba. Chick growth rates (A), and peak and fledging masses (B), at oiled (Naked Island) and unoiled (Jackpot Island) colonies in Prince William Sound, Alaska, before and after the 'Exxon Valdez' oil spill. Values are grand means ( $\pm 1 \mathrm{SE}$ ) of individual year means. Sample sizes are indicated at the bases of the bars

prey were delivered to chicks at the oiled site postspill compared to pre-spill $(U=0.0, \mathrm{p}=0.016$; Fig. $7 \mathrm{~A}$ ), and compared to the unoiled site post-spill ( $\mathrm{n}=4619$ identified prey items, $G=71, \mathrm{p}<0.001$; Fig. 7A). Although the availability of high-lipid schooling fishes appeared reduced at the oiled site following EVOS, this did not appear to affect meal delivery rates. There were no significant differences in the rate at which chick meals were delivered to the nests at the oiled site pre- versus post-spill $(U=9, \mathrm{p}=$ 0.73 ; Fig. 7B). Chick meal deliveries were significantly less frequent (when controlling for effects of 'year' and 'number of chicks in the nest'), however, at the oiled site post-spill compared to the unoiled site $\left(F_{1,82}=7.7, \mathrm{p}=0.007\right.$; Fig. 7B $)$. The post-spill difference in delivery rates between sites is not evident in
Fig. 7B because the values presented are yearly as opposed to least-squares means. In other words, the post-spill 'site' effect is masked in Fig. 7B by the effects of 'year' and 'number of chicks in the nest'.

\section{Chick growth and reproductive success}

Linear growth rates of chick mass tended to be higher at the oiled site pre- versus post-spill $(U=5, \mathrm{p}=$ 0.089; Fig. 8A), although no difference was observed post-spill between study sites $\left(F_{1,173}=0.32, \mathrm{p}=0.57\right.$; Fig. 8A). Differences in peak and fledging masses were not significantly different pre- versus post-spill (peak mass: $U=5.5, \mathrm{p}=0.10$; fledging mass: $U=9, \mathrm{p}=$ 0.34 ; Fig. 8B), although these parameters were both significantly lower post-spill at the oiled site compared to the unoiled site (peak mass: $F_{1,142}=8.7, \mathrm{p}=0.004$; fledging mass: $F_{1,137}=11.4, \mathrm{p}=0.001 ;$ Fig. $8 \mathrm{~B}$ ).

Differences in chick growth appear to have contributed to differences in reproductive success preversus post-spill at the oiled site. Guillemot productivity tended to be higher before EVOS than after $(U=7, \mathrm{p}=0.088$; Fig. 9). The trend of higher pre-spill productivity at the oiled site was the result of significantly higher nestling survival pre-spill compared to post-spill $(U=0.0, p=0.004$; Fig. 9), as hatching success was actually lower at the oiled site before the spill than after the spill $(U=32, \mathrm{p}=0.018$; Fig. 9). Contributing to the lower post-spill productivity was a significantly higher rate of predation of guillemot eggs and chicks after EVOS $(40 \pm 9 \%$ of nests depredated, $\mathrm{n}=7 \mathrm{yr})$ compared to before EVOS $(6 \pm 2 \%$ of nests depredated $\times$ nests with eggs ${ }^{-1}, \mathrm{n}=5 \mathrm{yr}, U=$ $35, \mathrm{p}=0.004)$. When considering pre- and post-spill

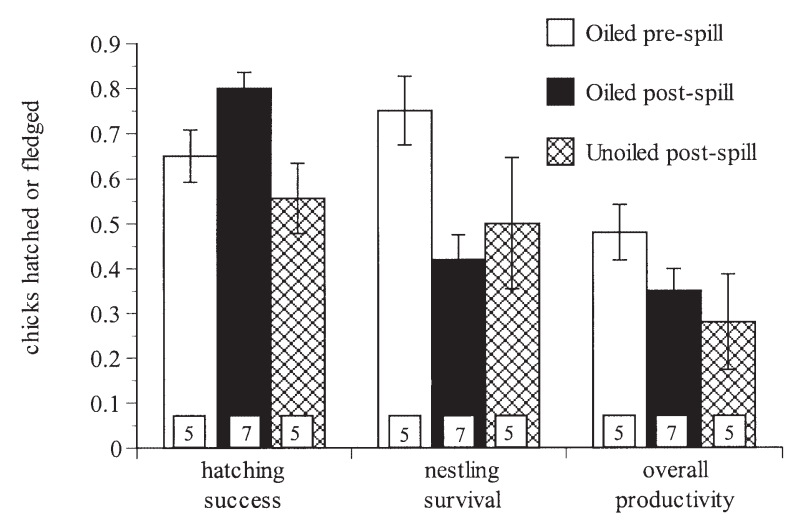

Fig. 9. Cepphus columba. Reproductive success at oiled (Naked Island) and unoiled (Jackpot Island) colonies in Prince William Sound, Alaska, before and after the 'Exxon Valdez' oil spill. Values are grand means $( \pm 1 \mathrm{SE})$ of individual year means. Sample sizes are indicated at the bases of the bars 
years collectively at the oiled site, productivity was found to be significantly related to predation rate $(y=$ $\left.-0.47 x+0.57, \mathrm{n}=12 \mathrm{yr}, \mathrm{r}^{2}=0.57, \mathrm{p}=0.004\right)$. No difference was observed in clutch size between the oiled site pre- $\left(1.7 \pm 0.03\right.$ eggs nest $\left.^{-1}, \mathrm{n}=5 \mathrm{yr}\right)$ versus post-spill $\left(1.7 \pm 0.03\right.$ eggs nest $^{-1}, \mathrm{n}=7 \mathrm{yr}, U=14.5$, $\mathrm{p}=0.81)$.

Although chicks attained higher peak and fledging masses post-spill at the unoiled site than the oiled site, no difference was observed in overall productivity $(\mathrm{n}=$ 596 eggs, $G=0.14, \mathrm{p}=0.71$; Fig. 9). Predation of guillemot eggs and chicks was significantly higher at the oiled site post-spill than at the unoiled site $(23 \pm 16 \%$ of nests depredated nests with eggs ${ }^{-1}, \mathrm{n}=367$ nests, $G=12.9, \mathrm{p}<0.001)$; however, nestling survival was not significantly different post-spill between sites ( $\mathrm{n}=369$ chicks, $G=0.26, \mathrm{p}=0.65$; Fig. 9). Clutch size was significantly lower post-spill at the oiled site than the unoiled site $\left(1.8 \pm 0.03\right.$ eggs nest $^{-1}, \mathrm{n}=363$ nests, $G=$ $6.0, \mathrm{p}=0.015)$, although post-spill hatching success was higher at the oiled site ( $\mathrm{n}=609$ eggs, $G=40.9, \mathrm{p}<$ 0.001; Fig. 9).

\section{DISCUSSION}

In the decade following EVOS, guillemot populations in oiled areas did not show any signs of recovery. Ten years is, however, a sufficient amount of time for this species to increase in number (given its reproductive rate, age at first breeding, etc.) if conditions are sufficiently favorable (Samuels \& Lanfear 1982). That impacted populations have not rebounded indicates that some mechanism(s) other than intrinsic demographic constraints limited post-spill population growth of guillemots in oiled areas. Our analyses suggest 2 such mechanisms: a direct effect whereby continued exposure to residual oil reduced adult survival, and an indirect effect whereby the oil spill impacted an important forage fish species, thereby reducing fledging mass and subsequent survival.

\section{Continuing exposure to oil}

In 1997, adult guillemots at the oiled site had elevated AST activities relative to the unoiled site, suggesting possible liver injury (Seiser et al. 2000). Because the 1997 study had a small sample size, however, these results were considered preliminary. Analysis of the samples we collected over the next 2 yr corroborated the 1997 results. Elevated CYP1A suggests that adult guillemots at the oiled site were exposed to residual oil, and a significant positive correlation between CYP1A and AST activity among individual birds strongly suggests that petroleum hydrocarbon exposure caused organ damage. Collectively, these results suggest that continued exposure to residual oil may have directly limited recovery of guillemots by reducing survival of adult birds. Indeed, a relatively small increase in adult mortality is sufficient to explain a lack of recovery (see below). The suggestion that oil exposure may have reduced the survival of adult guillemots inhabiting oiled areas of PWS is made more plausible given findings of concurrent studies conducted on other nearshore vertebrate predators in PWS. Elevated CYP1A activities, suggestive of continued exposure to residual oil, have been detected for Barrow's goldeneyes Bucephala islandica, harlequin ducks Histrionicus histrionicus (Trust et al. 2000), sea otters Enhydra lutris (Bodkin et al. 2002), river otters Lutra canadensis (Ballachey et al. 2000), and masked greenling Hexagrammos octogrammus (Jewett et al. 2002). Most noteworthy, in the 2 species in which adult survival was studied (harlequin ducks and sea otters), significant reductions in over-winter survival were found for populations inhabiting oiled sites (Esler et al. 2000, Monson et al. 2000). Reduced survival in these studies was observed through at least 1998, suggesting relatively long-term mortality effects associated with the 1989 spill.

That adult guillemots, but not chicks, at the oiled site had elevated CYP1A suggests that differences in diet or habitat use resulted in differential exposure to oil. Because chicks are sheltered in nest cavities, their only opportunities for oil exposure are through their food (almost exclusively fishes [Golet et al. 2000]) or physical contact with their parents. Adults have greater opportunities for exposure because they have wider dietary breadth, consuming both fishes and invertebrates, (Eldridge \& Kuletz: unpubl. report to US Fish and Wildlife Service 1980), and inhabit nearshore areas that were heavily contaminated with 'Exxon Valdez' oil. Invertebrate feeders are more likely to ingest toxins than piscivorous species, as invertebrates typically sequester and accumulate toxins while fishes metabolize them (Roesijadi et al. 1978, Varanasi et al. 1989).

Although CYP1A was significantly elevated among adults at the oiled site relative to the unoiled site, levels were low at both sites. Absolute levels of CYP1A expression are difficult to interpret, however, because it is not known what level of exposure is needed to elicit a response of the magnitude observed. Also, because CYP1A values were determined only from breeding birds, they may underestimate exposure levels of the oiled population at large. Higher exposure levels may have existed among non-breeders, as oiling has been shown to reduce egg laying in other alcids 
(e.g. Cassin's auklet Ptychoramphus aleuticus: Ainley et al. 1981).

High corticosterone and glucose concentrations among adult guillemots at the oiled site are suggestive of active mobilization of energy substrates (Wingfield 1994), which can occur following exposure to oil. Studies of both externally-oiled penguins (Fowler et al. 1995) and oil-fed nestling seabirds (Peakall et al. 1981) demonstrated elevated levels of corticosterone relative to unoiled controls. Experimental studies in mallards Anas platyrhynchos, however, showed that ingested oil suppressed adrenocortical function (Gorsline \& Holmes 1982). Because oil exposure affects birds through multiple pathways (e.g. thermoregulatory and physiological), variable adrenocortical responses may be expected. Additional research is needed to better understand under what circumstances oil exposure leads to increased versus decreased levels of circulating corticosterone.

Our assessment of effects of oiling on reproductive performance is incomplete (and conservative), as we were unable to determine whether or not exposure to residual oil resulted in greater instances of non-breeding at the oiled colony. Comparisons of breeders are nonetheless informative, as oil exposure can affect factors other than breeding propensity in birds (Leighton 1993). Chick growth and reproductive success patterns observed at the oiled and unoiled sites pre- and postspill suggest that the level of oil exposure experienced among breeding adults at Naked Island was insufficient to cause reproductive impairment. Although guillemot chick growth rates were higher at the oiled site pre- versus post-spill, growth rates at the oiled site after EVOS compare favorably with values reported in the literature (Drent 1965, Ainley et al. 1990, Emms \& Verbeek 1991,Vermeer et al. 1993). Indeed, the difference in chick growth at the oiled site between these 2 periods appears not to be a function of depressed rates of growth after the spill, but rather the result of exceptionally high growth rates pre-spill (Golet et al. 2000). Our finding that chick growth rates did not differ postspill between oiled and unoiled sites provides additional evidence that residual oil exposure was not affecting chicks. Peak and fledging masses of the chicks were significantly lower following the spill at the oiled site than at the unoiled site; however, it is unlikely that this was a direct result of oil exposure. Oil effects on chick development are more typically manifested when chicks are young (Leighton 1993). Productivity was significantly higher at the oiled site preversus post-spill due to differences in nestling survival; however, the weight of evidence does not suggest that this resulted from oiling effects. Lower nestling survival following the spill was more likely to have been the result of reduced availability of high-lipid forage fishes (see below), although high levels of predation on guillemot nestlings post-spill also contributed.

\section{Forage-fish availability}

By examining population trajectories, chick diet, chick growth, and reproductive success between the oiled and unoiled colonies pre- and post-spill, insight can be gained into the mechanistic role that availability of high-lipid forage fishes may have played in limiting the recovery of guillemot populations in PWS following EVOS.

Chick diet data suggest that availability of high-lipid forage fishes was lower at the oiled site following the spill than at both the oiled site pre-spill and the unoiled site post-spill. Although we did not directly assess high-lipid forage fish availability, recent work has shown that the diet of nestling pigeon guillemots reflects the spatial and temporal abundance of these prey in the environment (Litzow et al. 2000). High-lipid fishes are clearly important to guillemots, as the percent of this prey type in the chick diet has been positively related to chick growth rates, nestling survival, and overall productivity (Golet et al. 2000).

In the present study, a decrease in the percent of high-lipid forage fishes in the chick diet at the oiled site after the spill was associated with a decrease in post-spill reproductive performance, suggesting that reduced availability of this prey type may have constrained the recovery of impacted guillemot populations following the oil spill. Compared to pre-spill, post-spill nestling survival at the oiled site was significantly lower, and chick growth and overall productivity also tended to be lower.

A comparison of chick diet and reproductive performance between oiled and unoiled sites after EVOS further suggests that availability of high-lipid forage fishes may have affected recovery. Following the spill, high-lipid fishes formed a higher percentage of the chick diet at the unoiled site than the oiled site, and once again the more lipid-rich diet appeared to confer reproductive benefits. The unoiled site is situated adjacent to several bays that are nursery areas for Pacific herring Clupea pallasii (Norcross et al. 1996), a highlipid forage fish that typically comprised about $45 \%$ of the chick diet of guillemots at this site (Appendix 2), and that presumably offset the lower demersal foragefish availability (as determined by dive surveys) in this area. Chicks at the unoiled site had significantly higher peak and fledging masses (by 29 and $31 \mathrm{~g}$, respectively) than chicks at the oiled site, and recent work on captive seabirds suggests that the benefits of a high-lipid diets to nestlings may be greater than are appreciated by comparisons of body mass alone. 
Romano (2000) found that at fledging, chicks fed highlipid fishes had double the fat reserves of chicks fed isocaloric low-lipid diets, although there were no significant differences between the 2 groups in fledging masses. Larger body masses and greater fat reserves are thought to enhance fledgling survival probabilities in birds (especially in species such as guillemots, where chicks receive no parental care after leaving the nest), presumably because they buffer the young from periods of low caloric intake that may follow fledging (Perrins et al. 1973, Jarvis 1974, Gaston 1997).

Using a Leslie population-projection matrix (Leslie 1945, Krebs 1994), we calculated the reduction in fledgling survival that was required at the oiled site to explain the divergent population trajectories observed at the 2 sites post-spill. The matrix reduced to:

$$
P_{F}=\left(\left[N_{X} \times \lambda\right]-\left[N_{X} \times P_{A}\right]\right) /\left(F_{X} \times P_{A}^{2}\right)
$$

In this equation, fledgling survival $\left(P_{F}\right)$ is calculated from the population size $\left(N_{\mathrm{x}}\right)$, the population multiplication rate $(\lambda)$, and the number of offspring $\left(F_{x}\right)$ produced at each site $\left(F_{X}\right.$ was calculated from measures of clutch size and productivity, see Appendixes 1 and 2). The model assumes stable age distributions, sex ratios of adults and offspring equal to 0.5 , that $10 \%$ of the population is nonbreeding, and an age-constant adult (>1 yr) survival $\left(P_{A}\right)$ of 0.90 . Although this model is simplistic, it is informative, as it suggests that fledgling survival must be $41 \%$ lower at the oiled than the unoiled site (0.37 vs 0.81$)$ to explain the population trends. Although we cannot be certain that the observed difference in mean fledging weights translated into a difference in fledgling survival, this analysis presents us with a plausible mechanism to explain the lack of recovery of guillemots at the oiled colonies.

A lack of recovery may also have been caused by increased levels of adult mortality at the oiled site after the spill (a direct oil-spill effect, see above). If we apply the same analysis technique, but this time hold fledgling survival constant (at 0.75), we can calculate what difference in adult survival is necessary to explain the divergent population trends. A reduction in survival of $7 \%$ (from 0.91 to 0.84 ) at the oiled site is sufficient to explain the observed rate of population growth at the oiled site.

High levels of predation of guillemot eggs and chicks at the oiled site following the spill also appear to have played a role in limiting recovery, but it is unlikely that this was the sole explanation for the lack of population growth at the oiled colonies post-spill. Instances of egg and chick predation are incorporated into productivity parameters, and overall productivity did not differ significantly between the oiled and unoiled sites postspill. Our finding that the population at the unoiled site increased even though its post-spill reproductive suc- cess was not higher than that observed at the oiled colony suggests that factors other than nest predation limited population recovery of oil-impacted colonies. Predation could have limited recovery, however, if more adult birds were killed by predators at the oiled site post-spill.

Although we lack pre-spill data on sand lance abundance, it is likely that this high-quality foragefish species was negatively affected by the spill. Sand lance depend on fine gravel or sandy beaches, habitats that were contaminated extensively by 'Exxon Valdez' oil (O'Clair et al. 1996) and that typically retain toxic fractions of crude oil (PAHs) longer than other habitat types (Conan 1982). Sand lance burrow in beach sediments to gain refuge from predators, and seasonally spawn (in a manner that leaves scoured pits) in the same habitat (Robards et al. 1999). Both activities present obvious avenues of oil exposure. Experimental work has shown that sand lance avoid oiled substrates (Pinto et al. 1984) and spend significantly more time in the water column, thereby exposed to predators, when beach sediments are contaminated (Pearson et al. 1984). Furthermore, Stagg \& McIntosh (1996) found a significant relationship between petroleum hydrocarbon concentration in the water and CYP1A in Ammodytes marinus (the ecological counterpart of $A$. hexapterus in the Atlantic Ocean), suggesting that Ammodytes spp. are exposed to oil when their habitat is contaminated. Low concentrations of Prudhoe Bay crude oil are toxic to these fishes, and significant histological damage results when water-suspended oil droplets pass over their gills (Anderson 1985). Also, because sand lance exhibit strong site-fidelity (Hobson 1986), it may take several yr for an impacted population to recover, even in the absence of continuing oil spill effects. Observations that sand lance abundance increased from 1995 to 1999 at the oiled site (E. Brown unpubl. data) are consistent with the notion that local populations were reduced by EVOS.

Reduced availability of high-quality fishes at the unoiled site following the spill could also have resulted from a natural shift in prey communities, as a largescale regime shift in forage-fish species took place in the northern Gulf of Alaska during the late 1970s and early 1980s (Anderson \& Piatt 1999). An examination of seabird diets in the Gulf of Alaska does not, however, support the notion that sand lance declined during this period. Indeed, piscivorous seabirds in the northern Gulf of Alaska shifted from a diet that was dominated by capelin in the early years to one that was primarily sand lance in the late 1980s (Piatt \& Anderson 1996). Further evidence that sand lance did not decline in abundance during the regime shift comes from studies conducted in Kachemak Bay, Alaska. Robards et al. 
(1999) analyzed beach seine data collected in 1976, 1995 and 1996, and found no decline over this interval in sand lance catch per unit effort or percent occurrence.

\section{Recovery of seabird populations following oil spills}

Dunnet (1982) concluded that, in general, oil spills do not represent much of a threat to seabird populations. His conclusion, however, was based upon a comparison of natural levels of mortality and oil-induced mortality, with the former being an order of magnitude greater than the latter. Also, the seabirds in the region studied were experiencing a 'particularly favourable general environment' with nearly all populations increasing. If, as Dunnet acknowledged, oil-induced mortalities were greater, or if conditions were less favorable for seabirds, then mortalities due to oil pollution could have been much more significant in terms of population dynamics. For guillemots in PWS, oilinduced impacts appeared to have significant and lingering effects on populations.

Our study demonstrates that seabird populations cannot always be expected to rebound to preperturbation levels in the short term following a massmortality event. Furthermore, it suggests that recovery times following oil spills may be considerably longer for certain species than a few yr, which was proposed as typical for marine birds (Wiens et al. 1996, Day et al. 1997). For recovery to occur, impacted populations must not only replace individuals that are lost due to normal levels of attrition, but they must also replace individuals that were lost in the perturbation event. In the case of pigeon guillemots and EVOS, recovery of oiled populations did not take place in the decade following the spill, and this may be due to effects that were both direct (continued exposure of adults to lingering oil) and indirect (oil-spill impacts on an important prey species).

To better understand how oil spills impact seabird populations, future research should more closely examine the physiological effects of oil on both seabirds and their prey (i.e. key forage fish species such as Pacific sand lance). Dose-response studies have the potential to increase our understanding of the level of oil exposure required to manifest enzymatic responses such as those observed in this study, and histopathological investigations may permit better assessments of the longterm consequences of such exposures. Advances along these lines as well as in our understanding of how natural environmental variability influences fundamental demographic characteristics will improve our ability to identify mechanisms that constrain the recovery of seabird populations impacted by oil spills.

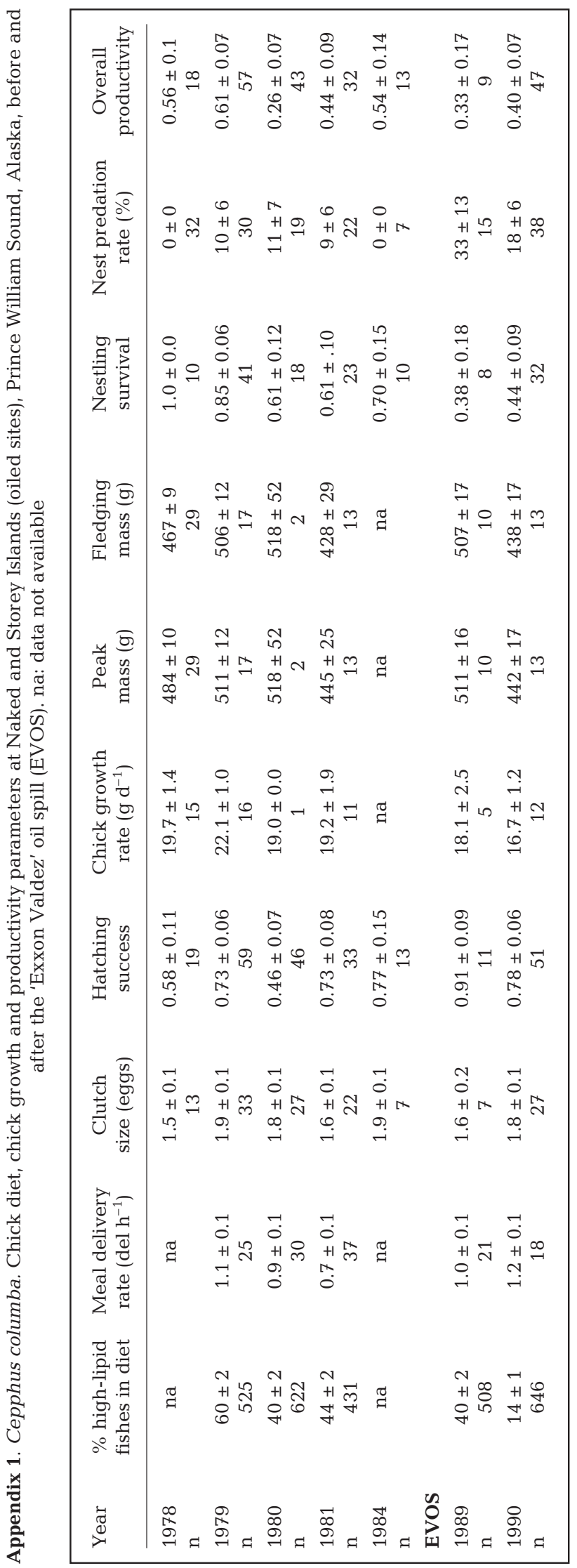




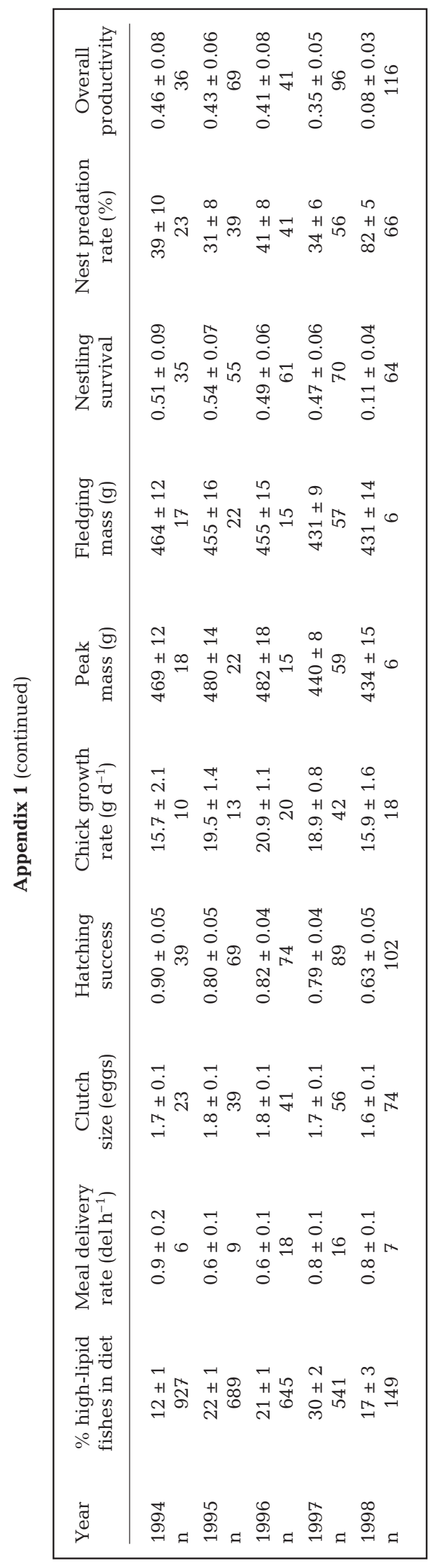

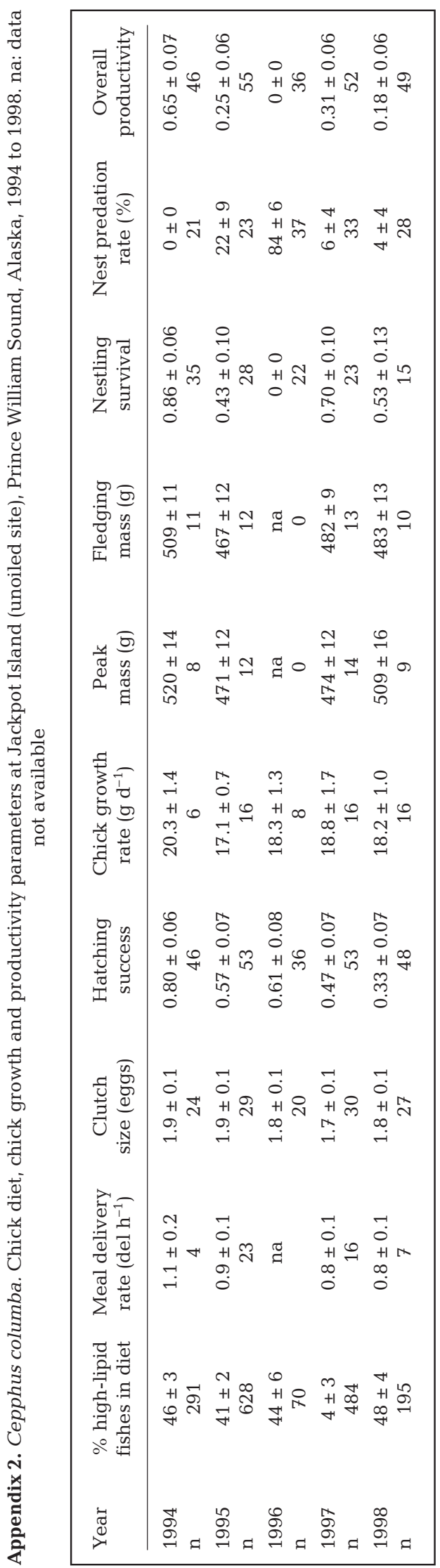


Acknowledgements. We thank L. Ballock, G. Blundell, M. Cody, B. Duggan, A. Gall, C. Geissler, A. Hahn, J. Hamon, D. L. Hayes, P. Joy, C. Kuntzsch, K. Lenington, M. Luanglue, D. Malefant, J. Maniscalco, A. McKnight, A. Palmer, C. Restrepo, M. Russell, S. Shaffer, B. Short, T. Spencer, O. Sternicki, K. Sullivan, D. Tessler, E. Vorisek, M. Walgren, and D. Ziel for valuable field assistance. L. Degernes performed liver biopsy surgeries, while C. Harms and K. Trust administered anesthesia. This manuscript was improved thanks to insightful discussions with B. Ballachey, M. Litzow, K. Oakley, and M. Robards. Dr. M. Christopher (University of California Davis School of Veterinary Medicine) provided helpful interpretations of the blood data. T. Gotthardt produced the study site figures. We are grateful to G. Spencer for critically reviewing an earlier draft of this manuscript. This study was supported by the US Fish and Wildlife Service, the Exxon Valdez Oil Spill Trustees Council, and grant no. BAA52ABNF400104 from NOAA to D.D.R. This study was a component of, but does not necessarily reflect the views of, the EVOS Trustee Council-funded Alaska Predator Ecosystem Experiment (APEX) and Nearshore Vertebrate Predator Project during 1994 to 1999. Permission to work on Naked and Jackpot Islands was granted by the US Forest Service.

\section{LITERATURE CITED}

Agler BA, Kendall SJ, Irons DB, Klosiewski SP (1999) Declines in marine bird populations in Prince William Sound, Alaska coincident with a climatic regime shift. Waterbirds 22:98-103

Agresti A (1990) Categorical data analysis. John Wiley, New York

Ainley DG, Grau CR, Roudybush TE, Morrell SH, Utts JM (1981) Petroleum ingestion reduces reproduction in Cassin's auklets. Mar Pollut Bull 12:314-317

Ainley DG, Boekelheide RJ, Morrell SH, Strong CS (1990) Pigeon Guillemot. In: Ainley DG, Boekelheide RJ (eds) Seabirds of the Farallon Islands. Stanford University Press, Stanford, p 276-305

Anderson JW (1985) Toxicity of dispersed and undispersed Prudhoe Bay crude oil fractions to shrimp, fish, and their larvae. Publ. No. 4441. American Petroleum Institute, Washington, DC, p 1-18

Anderson PJ, Piatt JF (1999) Community reorganization in the Gulf of Alaska following ocean climate regime shift. Mar Ecol Prog Ser 189:117-123

Andres BA (1999) Effects of persistent shoreline oil on breeding success and chick growth in black oystercatchers. Auk 116:640-650

Anthony JA, Roby DD, Turco KR (2000) Lipid content and energy density of forage fishes from the northern Gulf of Alaska. J Exp Mar Biol Ecol 248:53-78

Ballachey BE, Stegeman JJ, Snyder PW, Blundell GM and 10 others (2000) Oil exposure and health of nearshore vertebrate predators in Prince William Sound following the 1989 Exxon Valdez oil spill. In: Holland-Bartels LE (ed) Mechanisms of impact and potential recovery of nearshore vertebrate predators following the 1989 Exxon Valdez oil spill. Exxon Valdez Oil Spill Trustee Council Restoration Project Final Report (Restoration Project 95025-99025), US Geological Survey, Alaska Biological Science Center, Anchorage, AK, p 2.1-2.58

Barrett RT, Anker-Nilssen T, Rikardsen T, Valde K, Rov N, Vader W (1987) The food, growth and fledging success of Norwegian Puffin chicks Fratercula arctica in 1980-83. Ornis Scand 18:73-83
Ben-David M, Williams TM, Ormseth OA (2000) Effects of oiling on exercise physiology and diving behavior of river otters: a captive study. Can J Zool 78:1380-1390

Birkhead TR, Hudson PJ (1977) Population parameters for the common guillemot (Uria aalge). Ornis Scand 8:145-154

Bishop YM, Fienberg SE, Holland PW (1975) Discrete multivariate analysis: theory and practice. MIT Press, Cambridge

Bodkin JL, Ballachey BE, Dean TA, Fukuyama AK and 5 others (2002) Sea otter population status and the process of recovery from the 1989 'Exxon Valdez' oil spill. Mar Ecol Prog Ser 241:237-253

Boersma PD, Parrish JK, Kettle AB (1995) Common murre abundance, phenology, and productivity on the Barren Islands, Alaska: the Exxon Valdez oil spill and long-term environmental change. In: Wells PG, Butler JN, Hughes JS (eds) Exxon Valdez oil spill: fate and effects in Alaskan waters. American Society for Testing and Materials, Philadelphia, PA, p 820-853

Bourne WRP, Parrack JD, Potts GR (1967) Birds killed in the Torrey Canyon disaster. Nature 215:1123-1125

Bowyer RT, Testa WJ, Faro JB (1995) Habitat selection and home ranges of river otters in a marine environment: effect of the Exxon Valdez oil spill. J Mammal 76:1-11

Brekke B, Gabrielsen GW (1994) Assimilation efficiency of adult kittiwakes and Brünnich's guillemots fed capelin and arctic cod. Polar Biol 14:279-284

Butler RG, Lukasiewicz P (1979) A field study of the effects of crude oil on herring gull (Larus argentatus) chick growth. Auk 96:808-812

Campbell TW (1986) Selected biochemical tests used to detect the presence of hepatic disease in birds. In: 1986 AAV Proceedings. Association of Avian Veterinarians, Miami, Florida, p 43-51

Collier TK, Varanasi U (1991) Hepatic activities of xenobiotics in English sole (Parophrys vetulus) exposed to environmental contaminants. Arch Environ Contam Toxicol 20: $462-473$

Conan G (1982) The long-term effects of the Amoco Cadiz oil spill. Philos Trans R Soc Lond B Biol Sci 297:323-333

Culik BM, Wilson RP, Woakes AT, Sanudo F (1991) Oil pollution of Antarctic penguins: effects on energy metabolism and physiology. Mar Pollut Bull 22:388-391

Day RH, Murphy SM, Wiens JA, Hayward GD, Harner EJ, Smith LN (1997) Effects of the Exxon Valdez oil spill on habitat use by birds in Prince William Sound, Alaska. Ecol Appl 7:593-613

Dean TA, Bodkin JL, Fukuyama AK, Jewett SC, Monson DH, O'Clair CE, VanBlaricom GR (2002) Food limitation and the recovery of sea otters following the Exxon Valdez oil spill. Mar Ecol Prog Ser 241:255-270

Degernes LA, Harms CA, Golet GH, Mulchay DM (2002) Anesthesia and liver biopsy techniques for pigeon guillemots suspected of exposure to crude oil in marine environments. J Am Vet Med Assoc (in press)

Drent RH (1965) Breeding biology of the pigeon guillemot, Cepphus columba. Ardea 53:99-160

Dunnet GM (1982) Oil pollution and seabird populations. Philos Trans R Soc Lond B Biol Sci 297:413-427

Emms SK, Verbeek NAM (1991) Brood size, food provisioning and chick growth in the pigeon guillemot Cepphus columba. Condor 93:943-951

Esler D, Schmutz JA, Jarvis RL, Mulcahy DM (2000) Winter survival of adult female harlequin ducks in relation to history of contamination by the Exxon Valdez oil spill. J Wildl Manag 64:839-847

Esler D, Bowman TD, Trust KA, Ballachey BE, Dean TA, 
Jewett SC, O'Clair CE (2002) Harlequin duck population recovery following the 'Exxon Valdez' oil spill: progress, process and constraints. Mar Ecol Prog Ser 241:271-286

Ewins PJ (1993) Pigeon Guillemot. In: Poole A, Gill R (eds) The birds of North America. Academy of Natural Sciences and American Ornithologists' Union, Philadelphia, Washington, DC

Fienberg SE (1970) The analysis of multi-dimensional contingency tables. Ecology 51:419-433

Fowler GS, Wingfield JC, Boersma PD (1995) Hormonal and reproductive effects of low levels of petroleum fouling in magellanic penguins (Spheniscus magellanicus). Auk 112: 382-389

Franson CJ (1981) Enzyme activities in plasma, liver, kidney of Black Ducks and Mallards. J Wildl Dis 18:481-486

Fry DM, Addiego LA, Grau CR, Kang A (1986) Reduced reproduction of wedge-tailed shearwaters exposed to weathered Santa Barbara crude oil. Arch Environ Contam Toxicol 15:453-463

Fry MF, Lowenstine LJ (1985) Pathology of common murres and Cassin's auklets exposed to oil. Arch Environ Contam Toxicol 14:725-737

Fukuyama AK, Shigenaka G, Hoff RZ (2000) Effects of residual Exxon Valdez oil on intertidal Protothaca staminea: mortality, growth, and bioaccumulation of hydrocarbons in transplanted clams. Mar Poll Bull 40:1042-1050

Galt JA, Lehr WJ, Payton DL (1991) Fate and transport of the Exxon Valdez oil spill. Environ Sci Technol 25:202-209

Gaston AJ (1985) Development of the young in the Atlantic alcidae. In: Nettleship DN, Birkhead TR (eds) The Atlantic Alcidae: the evolution, distribution and biology of the auks inhabiting the Atlantic Ocean and adjacent water areas. Academic Press, San Diego, p 319-354

Gaston AJ (1997) Mass and date at departure affect the survival of ancient murrelet Synthliboramphus antiquus chicks after departure from the colony. Ibis 139:673-678

Golet GH, Irons DB (1999) Raising young reduces body condition and fat stores in black-legged kittiwakes. Oecologia 120:530-539

Golet GH, Kuletz KJ, Roby DD, Irons DB (2000) Adult prey choice affects chick growth and reproductive success of pigeon guillemots. Auk 117:82-91

Gorsline J, Holmes WN (1982) Suppression of adrenocortical activity in mallard ducks exposed to petroleum-contaminated food. Arch Environ Contam Toxicol 11:497-502

Harris MP, Hislop JRG (1978) The food of young puffins Fratercula arctica. J Zool (Lond) 185:213-236

Harris MP, Wanless S (1984) The effect of the wreck of seabirds in February 1983 on auk populations on the Isle of May (Fife). Bird Study 31:103-110

Hayes MO, Michel J (1999) Factors determining the longterm persistence of Exxon Valdez oil in gravel beaches. Mar Pollut Bull 38:92-101

Hislop JRG, Harris MP, Smith JGM (1991) Variation in the calorific value and total energy content of the lesser sandeel (Ammodytes marinus) and other fish preyed on by seabirds. J Zool (Lond) 224:502-527

Hobson ES (1986) Predation on the Pacific sand lance, Ammodytes hexapterus (Pisces: Ammodytidae), during the transition between day and night in southwestern Alaska. Copeia 1986:223-226

Hussel DJT (1972) Factors regulating clutch size in arctic passerines. Ecol Monogr 42:317-364

Irons DB, Kendall SJ, Erickson WP, McDonald LL, Lance BK (2000) Nine years after the Exxon Valdez oil spill: effects on marine bird populations in Prince William Sound, Alaska. Condor 102:723-737
Jakob EM, Marshall SD, Uetz GW (1996) Estimating fitness: a comparison of body condition indices. Oikos 77:61-67

Jarvis MJF (1974) The ecological significance of clutch size in the South African gannet (Sula capensis Lichtenstein). J Anim Ecol 43:1-17

Jewett SC, TA Dean, BR Woodin, MK Hoberg, and JJ Stegeman (2002) Exposure to hydrocarbons ten years after the Exxon Valdez oil spill: evidence from cytochrome P4501A expression and biliary FACs in nearshore demersal fishes. Mar Environ Res 54:21-48

Khan RA, Ryan P (1991) Long term effects of crude oil on common murres (Uria aalge) following rehabilitation. Bull Environ Contam Toxicol 46:216-222

King JG, Sanger GA (1979) Oil vulnerability index for marine oriented birds. In: Bartonek JC, Nettleship DN (eds) Conservation of marine birds of northern North America: papers from the international symposium held at the Seattle Hyatt House, Seattle, Washington, 13-15 May 1975. US Fish and Wildlife Service, Washington, DC, p 227-239

Kingston PF (1995) The Exxon Valdez and Braer oil spills: a comparison of their impacts on the marine environment. In: Aktuelle Probleme der Meeresumwelt. Dtsch Hydrogr Z (Suppl)5:59-72

Krebs CJ (1994) Ecology, 4th edn. Harper Collins, New York

Leighton FA (1985) Morphological lesions in red blood cells from herring gulls and Atlantic puffins ingesting Prudhoe Bay crude oil. Vet Pathol 22:393-402

Leighton FA (1993) The toxicity of petroleum oils to birds. Environ Rev 1:92-103

Leslie PH (1945) On the use of matrices in certain population mathematics. Biometrika 33:183-212

Litzow MA, Piatt JF, Abrookire AA, Prichard AK, Robards MD (2000) Monitoring temporal and spatial variability in sandeel (Ammodytes hexapterus) abundance with pigeon guillemot (Cepphus columba) diets. ICES J Mar Sci 57 : 976-986

Massias A, Becker PH (1990) Nutritive value of food and growth in common tern Sterna hirundo chicks. Ornis Scand 21:187-194

Mazet JKA, Gardner IA, Jessup DA, Lowenstine LJ, Boyce WM (2000) Evaluation of changes in hematologic and clinical biochemical values after exposure to petroleum products in mink as a model for assessment in sea otters. Am J Vet Res 61:1197-1203

Miller DS, Peakall DB, Kinter WB (1978) Ingestion of crude oil: sublethel effects in herring gull chicks. Science 199: 315-317

Moeller A (1987) Variation in badge size in male house sparrows Passer domesticus: evidence for status signaling. Anim Behav 35:1637-1644

Monson DH, Doak DF, Ballachey BE, Johnson A, Bodkin JL (2000) Long-term impacts of the Exxon Valdez oil spill on sea otters, assessed through age-dependent mortality patterns. Proc Natl Acad Sci USA 97:6562-6567

Murphy KA, Suring LH, Iliff A (1999) Western Prince William Sound human use and wildlife disturbance model, Exxon Valdez oil spill restoration project final report. Part A. Restoration Project 98339. Chugach National Forest, Anchorage

Murphy SM, Day RH, Wiens JA, Parker KR (1997) Effects of the Exxon Valdez oil spill on birds: comparisons of preand post-spill surveys in Prince William Sound, Alaska. Condor 99:299-313

Neff JM, Owens EH, Stoker SW, McCormick DM (1995) Shoreline oiling conditions in Prince William Sound following the Exxon Valdez oil spill. In: Wells PG, Butler JN, Hughes JS (eds) Exxon Valdez oil spill: fate and effects in 
Alaskan waters. ASTM STP 1219, Am Soc Testing and Materials, Philadelphia, PA, p 312-346

Newman SH, Anderson DW, Ziccardi MH, Trupkiewicz JP, Tseng FS, Chistopher MM, Zinkl JG (2000) An experimental soft-release of oil-spill rehabilitated American coots (Fulica americana). II. Effects on health and blood parameters. Environ Pollut 107:295-304

Norcross BL, Hose JE, Frandsen M, Brown ED (1996) Distribution, abundance, morphological condition, and cytogenetic abnormalities of larval herring in Prince William Sound, Alaska, following the Exxon Valdez oil spill. Can J Fish Aquat Sci 53:2376-2387

Oakley KL, Kuletz KJ (1996) Population, reproduction, and foraging of pigeon guillemots at Naked Island, Alaska, before and after the Exxon Valdez oil spill. In: Rice SD, Spies RB, Wolfe DA, Wright BA (eds) Proc Exxon Valdez Oil Spill Symp. Am Fish Soc Symp 18:759-769

O'Clair CE, Short JW, Rice SD (1996) Contamination of intertidal and subtidal sediments by oil from the Exxon Valdez in Prince William Sound. In: Rice SD, Spies RB, Wolfe DA, Wright BA (eds) Proc Exxon Valdez Oil Spill Symp. Am Fish Soc Symp 18:61-93

Osenberg GW, Schmitt RJ, Holbrook SJ, Abu-Saba KE, Flegal AR (1994) Detection of environmental impacts: natural variability, effect size, and power analysis. Ecol Appl 4:16-30

Parrish JK, Boersma PD (1995) Muddy waters. Am Sci 83:112-11

Peakall DB, Shugart LR (1993) Biomarkers: research and application in the assessment of environmental health. Springer-Verlag, Berlin

Peakall DB, Hallett D, Miller DS, Butler RG, Kinter WB (1980) Effects of ingested crude oil on black guillemots: a combined field and laboratory study. Ambio 9:28-30

Peakall DB, Tremblay J, Kintner WB, Miller DS (1981) Endocrine dysfunction in seabirds caused by ingested oil. Environ Res 24:6-14

Pearson WH, Woodruff DL, Sugarman PC (1984) The burrowing behavior of sand lance, Ammodytes hexapterus: effects of oil-contaminated sediment. Mar Environ Res 11:17-32

Perrins CM, Harris MP, Britton CK (1973) Survival of Manx Shearwaters Puffinus puffinus. Ibis 115:535-548

Peterson CH (2001) The Exxon Valdez oil spill in Alaska: acute, indirect and chronic effects on the ecosystem. Mar Bio 39:1-103

Piatt JF, Anderson PJ (1996) Response of common murres to the Exxon Valdez oil spill and long-term changes in the Gulf of Alaska marine ecosystem. In: Rice SD, Spies RB, Wolfe DA, Wright BA (eds) Proc Exxon Valdez Oil Spill Symp. Am Fish Soc Symp 18:720-737

Piatt JF, Ford RG (1996) How many seabirds were killed by the Exxon Valdez oil spill? In: Rice SD, Spies RB, Wolfe DA, Wright BA (eds) Proc Exxon Valdez Oil Spill Symp. Am Fish Soc Symp 18:712-719

Piatt JF, Lensink CJ, Butler W, Kendziorek M, Nysewander DR (1990) Immediate impact of the Exxon Valdez oil spill on marine birds. Auk 107:387-397

Piersma T (1984) Estimating energy reserves of great crested grebes Podiceps cristatus on the basis of body dimensions. Ardea 72:119-126

Piersma T, Davidson NC (1991) Confusions of mass and size. Auk 108:441-444

Pinto JM, Pearson WH, Anderson JW (1984) Sediment preferences and oil contamination in the Pacific sand lance Ammodytes hexapterus. Mar Biol 83:193-204

Rattner BA, Melancon MJ, Custer TW, Hothems RL (1996) Cytochrome P450 and contaminant concentrations in nestling black-crowned night herons and their interrelation with sibling embryos. Environ Toxicol Chem 15:715-721

Editorial responsibility: Otto Kinne (Editor),

Oldendorf/Luhe, Germany
Reid WV (1987) The cost of reproduction in the glaucouswinged gull. Oecologia 74:458-467

Robards MD, Piatt JF, Rose GA (1999) Maturation, fecundity, and intertidal spawning of Pacific sand lance in the northern Gulf of Alaska. J Fish Biol 54:1050-1068

Roesijadi GJ, Anderson W, Blaylock JW (1978) Uptake of hydrocarbons from marine sediments contaminated with Prudhoe Bay crude oil: influence of feeding type of test species and availability of polycyclic aromatic hydrocarbons. J Fish Res Board Can 35:608-614

Romano MD (2000) Effects of diet on growth and development of nestling seabirds. MS thesis, Oregon State University, Corvallis, OR

Samuels WB, Lanfear KJ (1982) Simulations of seabird damage and recovery from oilspills in the northern Gulf of Alaska. J Environ Manag 15:169-182

Sanger GA, Cody MB (1994) Survey of pigeon guillemot colonies in Prince William Sound, Alaska: U.S.F.W.S. migratory bird management. Final Report, Restoration Project 93034. Anchorage, AK

Seiser PE, Duffy LK, McGuire AD, Roby DD, Golet GH, Litzow MA (2000) Comparison of Pigeon Guillemot, Cepphus columba, blood parameters from oiled and unoiled areas of Alaska eight years after the Exxon Valdez oil spill. Mar Pollut Bull 40:152-164

Sokal RR, Rohlf FJ (1995) Biometry, 3rd edn. Freeman, New York

Stagg RM, McIntosh A (1996) Hydrocarbon concentrations in the northern North Sea and effects on fish larvae. Sci Total Environ 186:189-201

Stowe TJ (1982) An oil spillage at a guillemot colony. Mar Pollut Bull 13:237-239

SYSTAT (1997) SYSTAT ${ }^{\circledR}$ 7.0. New statistics. SPSS, Chicago

Trivelpiece WZ, Butler RG, Miller DS, Peakall DB (1984) Reduced survival of chicks of oil-dosed adult Leach's storm-petrels. Condor 86:81-82

Trust KA, Esler D, Woodin BR, Stegeman JJ (2000) Cytochrome P450 1A induction in sea ducks inhabiting nearshore areas of Prince William Sound, Alaska. Mar Pollut Bull 40:397-403

Van Pelt TI, Piatt JF, Roby DD (1997) Proximate composition and energy density of some North Pacific forage fishes. Comp Biochem Physiol 118A:1393-1398

Varanasi U, Stein JE, Nishimoto M (1989) Biotransformation and disposition of PAH in fish. In: Varanasi U (ed) Metabolism of polycyclic aromatic hydrocarbons in the aquatic environment. CRC Press, Boca Raton, FL, p 1-40

Vermeer K, Morgan KH, Smith GEJ (1993) Colony attendance of pigeon guillemots as related to tide height and time of day. Colon Waterbirds 16:1-8

Wiens JA, Crist TO, Day RH, Murphy SM, Hayward GD (1996) Effects of the Exxon Valdez oil spill on marine bird communities in Prince William Sound, Alaska. Ecol Appl 6:828-841

Wingfield JC (1994) Modulation of the adrenocortical response to stress in birds. In: Davey KG, Peter RE, Tobe SS (eds) Perspectives in comparative endocrinology. National Research Council, Ottawa, p 520-528

Wolfe DA, Hameedi MJ, Galt JA, Watabayashi G and 7 others (1994) Fate of oil spilled from the Exxon Valdez. Environ Sci Technol 28:561-568

Wolfe DA, Krahn MM, Casillas E, Sol S, Thompson TA, Lunz J, Scott KJ (1996) Toxicity of intertidal and subtidal sediments contaminated by the Exxon Valdez oil spill. In: Rice SD, Spies RB, Wolfe DA, Wright BA (eds) Proc Exxon Valdez Oil Spill Symp. Am Fish Soc Symp 18: 121-139

Submitted: July 18, 2000; Accepted: May 10, 2002

Proofs received from author(s): July 15, 2002 